\title{
Levonorgestrel Intrauterine System Effects versus Copper Intrauterine Device on Changing Of Menstruation and Uterine Artery Doppler
}

Gynecology and Women's Health Care

Research Article

\begin{tabular}{|c|c|c|}
\hline \multicolumn{3}{|c|}{$\begin{array}{l}\text { Nareman Elhamamy }{ }^{1^{*}} \\
{ }^{1} \text { Department of Obstetrics and Gynecology, Faculty of Medicine, Tanta University, Tanta, Egypt }\end{array}$} \\
\hline Submitted & $:$ March $17^{\text {th }}, 2020$ & Correspondence author \\
\hline Accepted & $:$ March 23 ${ }^{\text {rd }}, 2020$ & Nareman Elhamamy \\
\hline Published & $:$ March $26^{\text {th }}, 2020$ & $\begin{array}{l}\text { Lecturer of Obstetrics and Gynecology } \\
\text { Faculty of Medicine } \\
\text { Tanta University } \\
\text { Tanta } \\
\text { Egypt }\end{array}$ \\
\hline
\end{tabular}

\section{Abstract}

Background: The most effective methods for birth control are the long-acting reversible contraceptives LARCs include Paragard IUD in silver, Mirena IUD in hormonal (progesterone) and hormonal contraceptive implant. The intrauterine levonorgestrel-releasing system (LNG-IUS) and the intrauterine copper unit (Cu-IUD) influenced changing of menstruation and uterine artery Doppler indices Aim of the work: Comparison of the effects of copper intrauterine device (Cu-IUD) and an intrauterine levonorgestrel releasing system (LNG-IUS) on changing of menstruation and Doppler indices of uterine arteries.

Methods: This was RCT was completed between February 2017 to January 2020 at the Obstetrics and Gynecology department, Tanta University hospitals. There were two group first group $A: L N G-I U S(N=200)$ and second group $B C u$ IUD $(N=200)$, they were randomly assigned to 400 multiparous women preferring intrauterine contraception., the UA pulsatility index (PI) and the resistant index (RI) were determined at the beginning, and the associations with irregular bleeding were evaluated three and six months after insertion.

Results: In group A: LNG-IUS, some women registered irregular bleeding (28 percent) than in the Cu-IUD group (52 percent) at the beginning of the study $(P<0.001)$. There was bleeding irregularity (73 percent) in the group (A): LNG-IUS and severe menstrual bleeding (68 percent) in the Cu-IUD group. The uterine artery PI was associated with bleeding irregularity at value of 1.40, with a curve area $(A U C)$ of $0.91,90$ percent sensitivity, and 100 percent specificity. Uterine artery RI was associated with 0.65 with 0.22 AUC bleeding irregularity, 95 percent sensitivity and accuracy 100 percent.

Conclusion: LNG -IUS related irregular bleeding was linked to changes in the blood flow of uterine arteries that were not evident among $\mathrm{Cu}$ - IUD users.

Keywords: Intrauterine Devices, Lng-Ius, Cu-Iud, Long-Acting Reversible Contraception, Ultrasonography, Doppler, Color, Power Doppler

\section{Introduction}

Long acting reversible contraceptives (LARCs) are the most effective methods for regulating birth. LARCs include silver Paragard IUD, hormonal Mirena IUD (progesterone), and hormonal implant contraceptive. Such birth control methods can prevent unwanted pregnancies up to 20 times better than birth control pills, patches and vaginal rings [1].

The intrauterine levonorgestrel releasing system (LNGIUS) has demonstrated its effectiveness both as a long acting contraceptive and for its non-contraceptive advantages, including high efficacy in the treatment of severe menstrual bleeding. However, twenty-two and sixty seven percent of women had persistent or repeated bleeding in the first months after placement, which decreased by first year ending [2].

On the other hand, was associated with an increase of $30 \%$ to $50 \%$ in menstrual blood loss and about $10 \%$ to $20 \%$ in users requesting withdrawal by first year ending of use [3].

While some studies have indicated that the LNG-IUS raises the Doppler UA index three months after use due to an increased blood flow impedance in the uterine arteries [4-5]. Others found no changes in the Pulsatility Index (PI) or Resistance Index (RI) of the uterine artery between LNG-IUS users three months after insertion [6-7].

Similarly, studies of the indices of uterine artery Doppler reported contradictory results to identify the association between use of $\mathrm{Cu}-\mathrm{IUD}$ and heavy menstrual bleeding [8-9].

Knowing changes in the uterine vasculature among IUD users is important both in terms of physiological and pathophysiological changes to help inform women about their contraceptive choices [5]. 
The purpose of this study was to assess the impact of LNGIUS versus $\mathrm{Cu}$-IUD on menstrual changes and Doppler uterine artery indices 3 and 6 months after use.

\section{Materials and Methods}

The latest randomized clinical trial among new users of IUD was performed between January 2017 to August 2019 at the Obstetrics and Gynecology department, Tanta University hospitals. The study procedure had been accepted by the ethical review committee of the Faculty of Medicine, Tanta University.

The study included multiparous women attending a normal menstrual cycle at the family planning clinic who requested long acting reversible contraception and met the intrauterine contraception criteria after providing a complete history and undergoing clinical examination and transvaginal ultrasonography. Criteria is omitted: Nulliparity, pregnancy, previous month's genital infection, undiagnosed uterine bleeding, medical conditions and any contraindications to progestin administration or IUD insertion.

Participants were assigned to one of two classes by using computer-generated simple random tables. Women received group 1 LNG-IUS (Mirena, Bayer HealthCare, Berlin, Germany); women received group 2 copper T-380 IUD (Copper IUD, DPK, Egypt). Blinding was not done due to the clear distinction between the two forms of IUDs.

Uterine artery Doppler was conducted in the Department of Radiology with a 7-MHz transvaginal probe and an EUB7000 ultrasound instrument (Hitachi, Tokyo, Japan) prior to insertion of the contraceptive tool, and three and six months after insertion. For avoiding interobserver volatility.

The primary outcome measures were menstrual changes and improvements in the three and six months following application of uterine artery Doppler indices. In order to evaluate the correlation between uterine artery Doppler indices and subsequent regular or serious menstrual bleeding, a regression analysis included all women affected by an excessive bleeding at the three- and six-months follow-up. The secondary results were side effects, and female satisfactoriness.

Women were given calendars of menstruation to chart the days they suffered bleeding the WHO suggested. The menstrual segment included both a bleeding episode, and a bleeding-free cycle. Vaginal spotting was defined as very slight bleeding which did not require sanitary protection, while heavy bleeding was defined as hemorrhage which required sanitation. Analysis on side effects was done with appropriate managing of stated symptoms at each scheduled visit.

\section{Statistical Analysis}

Data entry, processing and statistical analysis was carried out using MedCalc ver. 18.2.1 (MedCalc, Ostend, Belgium).
Tests of significance (Kruskal-Wallis, Wilcoxon's, Chi square, logistic regression analysis, and Spearman's correlation) were used. Data were presented and suitable analysis was done according to the type of data (parametric and non-parametric) obtained for each variable. P-values less than $0.05(5 \%)$ was considered to be statistically significant.

To evaluate predictors of bleeding irregularity, multiple logistic regression was used. The feature of the receiver operator (ROC) curve analysis was used to determine the optimal cutoff value and sensitivity, and PI and RI specificity to predict bleeding. A $P$ value less than 0.05 has been found statistically significant. The confidence interval was set at $95 \%$ and the accepted error margin was set at $5 \%$. So, at the level of $<0.05$, the p-value was considered significant.

\section{Results}

Overall, 450 females met the study criteria and were employed into the clinical trial. Of these, the 6 month follow-up study was attended and completed by 400 women (LNG-IUS group, $\mathrm{n}=200$; $\mathrm{Cu}$-IUD group, $\mathrm{n}=200$ )
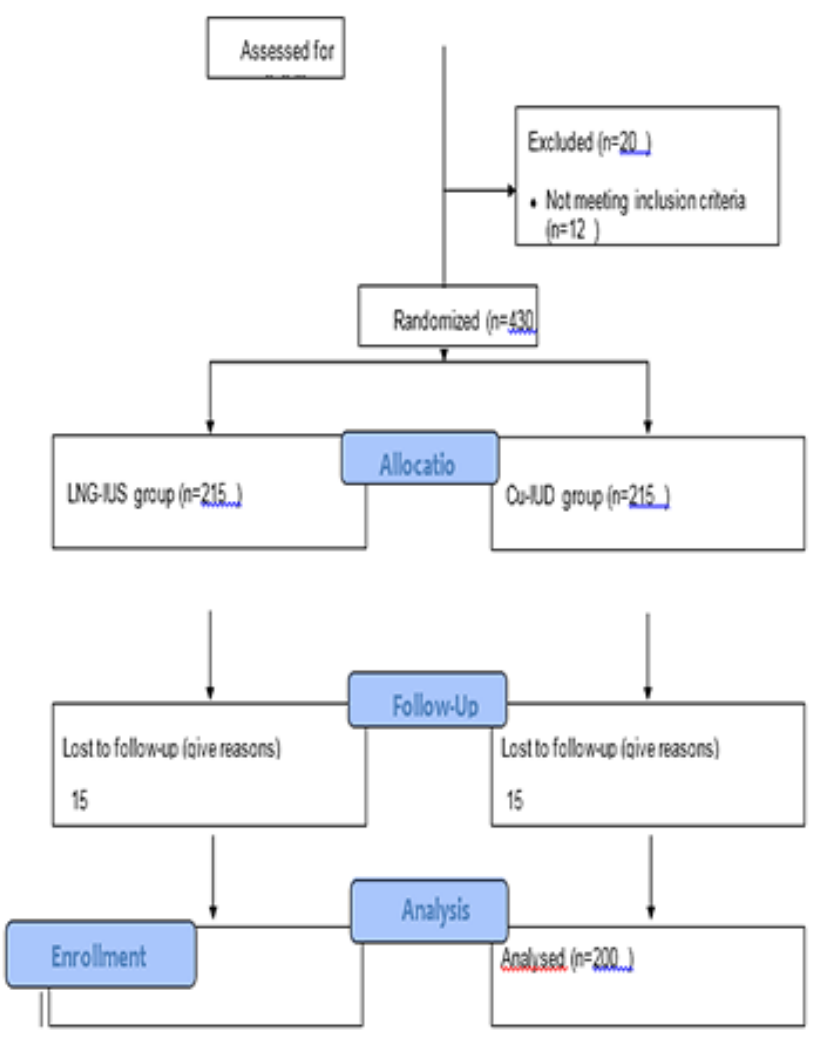

Figure 1: CONSORT flow diagram. 
Table (1): The sociodemographic characteristics among studied groups.

\begin{tabular}{|l|l|l|l|}
\hline & $\begin{array}{l}\text { Group A } \\
(\mathrm{N}=200)\end{array}$ & $\begin{array}{l}\text { Group B } \\
(\mathrm{N}=200)\end{array}$ & $P$ value \\
\hline Age $($ years $)$ & $32 \pm 1.24$ & $30 \pm 1.15$ & 0.16 \\
\hline BMI $\left(\mathrm{kg} / \mathrm{m}^{2}\right)$ & $24 \pm 0.76$ & $23.5 \pm 0.82$ & 0.461 \\
\hline Parity & $2.75 \pm 1.52$ & $2.82 \pm 1.59$ & 0.831 \\
\hline
\end{tabular}

Student's t test.

Table: 1 showing that no significant difference between the two groups regarding age, parity or body mass index was found).

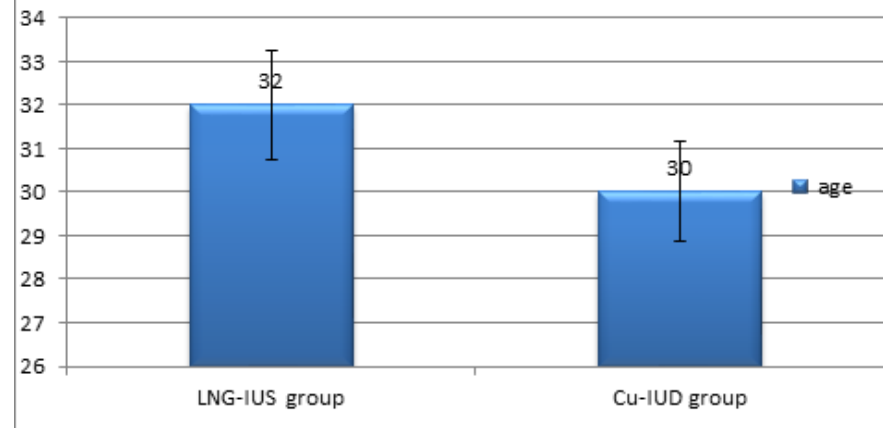

Fig. (2) Mean age of the studied group.

Table (2): The adverse effects and women acceptability of the contraceptive methods.

\begin{tabular}{|c|c|c|c|}
\hline & \begin{tabular}{|l|} 
Group A \\
$(\mathrm{N}=200)$
\end{tabular} & $\begin{array}{l}\text { Group B } \\
(\mathrm{N}=200)\end{array}$ & \begin{tabular}{|l|}
$\mathrm{P}$ \\
value \\
\end{tabular} \\
\hline Lower abdominal pain & $120(60 \%)$ & $150(75 \%)$ & 0.001 \\
\hline Back pain & $110(55 \%)$ & $160(80 \%)$ & 0.001 \\
\hline $\begin{array}{l}\text { Abnormal bleeding } \\
\text { - } \quad \text { Irregular bleeding } \\
\text { - } \quad \text { Heavy menstrual } \\
\text { bleeding }\end{array}$ & $\begin{array}{l}56(28 \%) \\
146(73 \%)\end{array}$ & $\begin{array}{l}104(52 \%) \\
136(68 \%)\end{array}$ & 0.016 \\
\hline $\begin{array}{ll}\text { Acceptability } \\
\text { - } & \text { Compliant follow- } \\
\text { up } \\
\text { - } & \text { Recommendation } \\
\text { to others } \\
\text { - Overall satisfaction }\end{array}$ & $\begin{array}{l}182(91 \%) \\
188(94.6 \%) \\
190(95.1 \%)\end{array}$ & $\begin{array}{l}170(85.2 \%) \\
166(83 \%) \\
150(75 \%)\end{array}$ & 0.06 \\
\hline
\end{tabular}

Table:2 showing that there was high statistically significant difference between two groups regarding side effects and acceptability of females two wards the contraceptive methods $(\mathrm{P}<0.001)$, at the beginning of the study, In LNG-IUS group fewer females had irregular bleeding ( 28 per cent) than in the $\mathrm{Cu}$-IUD group (52 per cent). The bleeding was primarily in the form of irregular bleeding (73 per cent) in the LNG-IUS community and extreme menstrual bleeding ( 68 per cent) in the
Cu-IUD group among those who had abnormal bleeding. The number of women experiencing irregular bleeding was down at six months in both groups. Also there was high statistically significant difference between two groups regarding overall satisfaction $(\mathrm{p}<0.05)$.

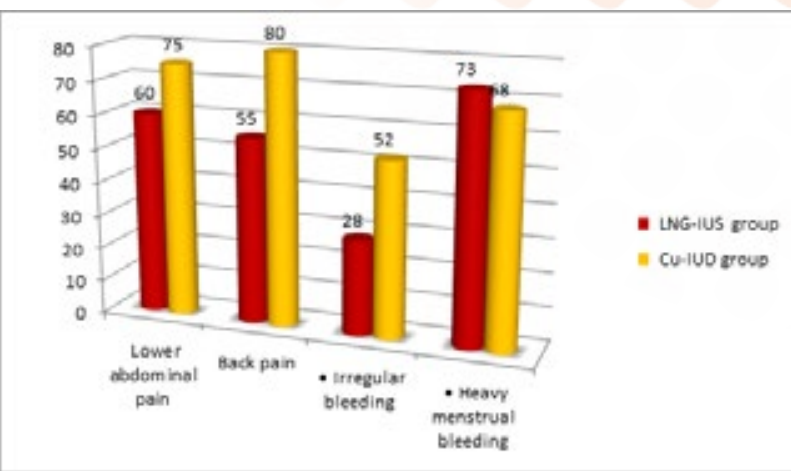

Fig (3): The side effects of contraceptive procedures in the studied groups

Table : Comparison between the studied groups regarding Uterine artery pulsatility index

\begin{tabular}{|c|c|c|c|c|c|c|}
\hline \multirow[t]{2}{*}{ Index } & \multicolumn{2}{|c|}{$\begin{array}{l}\text { Group A } \\
(\mathrm{N}=200)\end{array}$} & \multicolumn{2}{|c|}{$\begin{array}{l}\text { Group B } \\
(\mathrm{N}=200)\end{array}$} & \multirow{2}{*}{$\begin{array}{l}\text { Mann- } \\
\text { Whitney } \\
\text { U }\end{array}$} & \multirow[t]{2}{*}{$\begin{array}{l}\mathrm{P} \\
\text { value }\end{array}$} \\
\hline & $\begin{array}{l}(95 \% \\
\mathrm{CI})\end{array}$ & $\begin{array}{l}\mathrm{P} \\
\text { value* }\end{array}$ & $\begin{array}{l}(95 \% \\
\mathrm{CI})\end{array}$ & $\begin{array}{l}\mathrm{P} \\
\text { value* }\end{array}$ & & \\
\hline \multicolumn{7}{|l|}{$\mathrm{P} 1$} \\
\hline first & $\begin{array}{l}1.8 \\
(1.8- \\
2.2)\end{array}$ & & $\begin{array}{l}1.76 \\
(1.3- \\
1.8)\end{array}$ & & 8.721 & $<0.001$ \\
\hline 3 months & $\begin{array}{l}1.8 \\
(1.22- \\
2.2)\end{array}$ & $<0.001$ & $\begin{array}{l}1.8 \\
(1.16- \\
1.90)\end{array}$ & $<0.001$ & 1.821 & 0.351 \\
\hline 3 months & $\begin{array}{l}1.8 \\
(1.4- \\
2.2)\end{array}$ & $<0.001$ & $\begin{array}{l}1.8 \\
(1.21- \\
2.2)\end{array}$ & $<0.001$ & 2.921 & 0.031 \\
\hline
\end{tabular}

Versus first value

Table (4): Comparison between the studied groups regarding Uterine artery resistance index by study group.

\begin{tabular}{|c|c|c|c|c|c|c|}
\hline \multirow[t]{2}{*}{ Index } & \multicolumn{2}{|c|}{ Group $A(N=200)$} & \multicolumn{2}{|c|}{$\begin{array}{l}\text { Group B } \\
(\mathrm{N}=200)\end{array}$} & \multirow[t]{2}{*}{$\begin{array}{l}\text { Group A } \\
(\mathrm{N}=200)\end{array}$} & \multirow[t]{2}{*}{$\begin{array}{l}\text { Group B } \\
(\mathrm{N}=200)\end{array}$} \\
\hline & $(95 \% \mathrm{CI})$ & $\begin{array}{l}\mathrm{P} \\
\text { value* }\end{array}$ & $\begin{array}{l}(95 \% \\
\mathrm{CI}) \\
\end{array}$ & $\begin{array}{l}\text { P } \\
\text { value* }\end{array}$ & & \\
\hline \multicolumn{7}{|l|}{$\mathrm{RI}$} \\
\hline Initial & $\begin{array}{l}0.76(0.72- \\
0.79)\end{array}$ & & $\begin{array}{l}0.72 \\
(0.62- \\
0.78) \\
\end{array}$ & & 5.86 & $<0.001$ \\
\hline $\begin{array}{l}3 \\
\text { months }\end{array}$ & $\begin{array}{l}0.78(0.64- \\
0.82)\end{array}$ & $<0.001$ & $\begin{array}{l}0.77 \\
(0.61- \\
0.8)\end{array}$ & $<0.001$ & 0.947 & 0.344 \\
\hline $\begin{array}{l}6 \\
\text { months }\end{array}$ & $\begin{array}{l}0.74(0.61- \\
0.81)\end{array}$ & $<0.001$ & $\begin{array}{l}0.75 \\
(0.6- \\
0.82)\end{array}$ & $<0.001$ & 0.672 & 0.502 \\
\hline
\end{tabular}


Table 4 showing that there were significantly different regarding the first $\mathrm{PI}(\mathrm{P}<0.001)$ and $\mathrm{RI}(\mathrm{P}<0.001)$ were of which were higher among women in the LNG-IU group. Also, both groups at three and six months, that there were significantly different regarding PI and RI with the first Doppler indices (all $\mathrm{P}<0.001)$.

Table (5) : Multiple logistic regression analysis of bleeding abnormality and female features.

\begin{tabular}{|l|l|l|l|}
\hline Characteristic & $\begin{array}{l}\text { Odds ratio }(95 \% \\
\text { CI })\end{array}$ & $\mathrm{X}^{2}$ & P value \\
\hline Age & $1.01(0.96-1.15)$ & 0.941 & 0.531 \\
\hline BMI & $0.95(0.85-1.01)$ & 0.612 & 0.451 \\
\hline Parity & $0.74(0.52-1.01)$ & 4.01 & 0.061 \\
\hline Uterine PI & $5.75(2.51-15.3)$ & 12.96 & $<0.001$ \\
\hline Uterine RI & $8.50(2.82-18.65)$ & 20.31 & $<0.001$ \\
\hline
\end{tabular}

Table 5 showing that Multiple logistic regression analysis of bleeding abnormality and female features shown a significant correlation between uterine artery PI and RI at baseline $(\mathrm{P}<0.001)$

Table 4 ROC curve analysis of uterine artery Doppler indices to predict abnormal bleeding

\begin{tabular}{|l|l|l|l|l|}
\hline Parameter & AUC & $\begin{array}{l}\text { Cutoff } \\
\text { value }\end{array}$ & Sensitivity \% & Specificity \% \\
\hline $\begin{array}{l}\text { Uterine } \\
\text { artery PI }\end{array}$ & 0.91 & 0.22 & 90 & 100 \\
\hline $\begin{array}{l}\text { Uterine } \\
\text { artery RI }\end{array}$ & 1.40 & 0.65 & 95 & 100 \\
\hline
\end{tabular}

The ROC curve study associated uterine artery PI with irregular bleeding at a cutoff value of 1.40 with a curve area (AUC) of $0.91,90$ percent sensitivity, and 100 percent accuracy. Uterine artery RI was associated with 0.65 with 0.22 AUC bleeding irregularity, 95 per cent sensitivity\& accuracy. 100 per cent (Fig. 4 and Table 4).

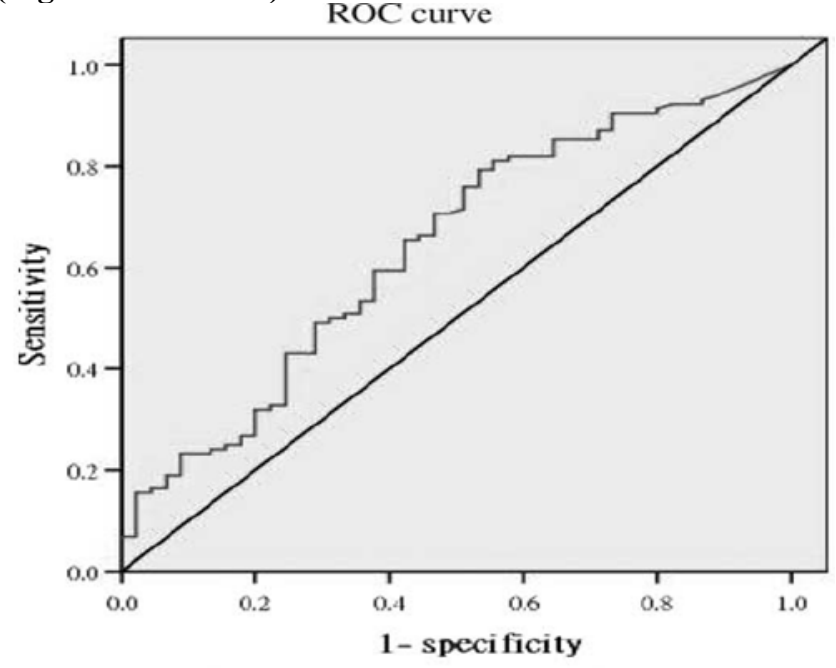

Diasonal serments are produced by ties

\section{Figure 4}

ROC curve analysis of the relationship between pulsatility index (PI) and resistance index (RI) of an irregular bleeding and uterine arteries.

\section{Discussion:}

Long acting reversible contraception (LARC) methods such as intrauterine levonorgestrel releasing (LNGIUS) are safe and highly effective in preventing pregnancy [14].

Previous studies had been done Doppler indices of the uterine artery and correlate with menstrual abnormalities reported conflicting results [4-6]. Women that use LNG-IUS will experience excessive or unusual bleeding in the first months following placement, as reported by $22 \%$ and $67 \%$ of users, respectively, and this abnormal bleeding will decrease by the end of the first year [2].

As expected, in this study, women using LNG-IUS reported lower rates of menstrual disorders and greater acceptability compared to cu-IUD, which could be largely attributed to menstrual irregularities and fear of declining future fertility. Women using LNG-IUS experienced greater acceptability in terms of overall satisfaction $(p<0.001)$ and method recommendation to other women $(\mathrm{p}<0.05)$.

In the current study, excessive uterine bleeding has been shown to be positively associated with hemodynamic changes in the uterine artery, with a significant decline in PI and RI among new users of LNG-IUS but not $\mathrm{Cu}-\mathrm{IUD}$.

Jiménez et al. [5] LNG-IUS first recorded positive effect on uterine artery PI. It was found that LNG-IUS was independently associated with increased uterine artery PI among 27 women after age and parity control, whereas in a study evaluating PI just before mid-luteal insertion and three months after insertion there was no difference among 25 women receiving TCU 380A IUD. Recently, more so.

Similarly, Järvelä et al., [4] Who in 13 postmenopausal symptomatic women who obtained transdermal estradiol 1 month before combining LNG-IUS with replacement estrogen therapy measured uterine PI. The same group subsequently stated in a study of 27 healthy, regularly menstruating women that LNG-IUS injection in the mid-luteal phase in combination with serum LNG and a associated decrease in serum progesterone tended to increase impedance to the uterine arterial blood flow.

Another longitudinal study Conducted by Bastianelli et al. [6] concluded that LNG-IUS not only altered endometrial thickness but also significantly altered uterine blood flow among women with excessive bleeding, Zalel et al. [10] After insertion of LNG-IUS in 47 women and insertion of Cu-IUD in 35 women, no changes in blood flow in the uterine artery were identified when measured prior to and after use. 
Dane et al. [11] Reduced sub endometrial vascularization and higher spiral artery uterine PI among 25 new users of Depomedroxyprogesterone acetate injection but no improvements among 25 new LNG-IUS users. More recently, Cihangir et al. [7] reported that there was no significant change in the volume of ovaries or uterine RI and PI at 6 or 12 months with respect to the pre-insertion values among 49 users of LNG-IUS.

Regarding the $\mathrm{Cu}-\mathrm{IUD}$, recent studies identified a lack of significant changes in the uterine artery's PI and RI with or without side effects, including dysmenorrhea, heavy menstruation and dyspareunia, 3 or 6 months after insert. [5, 9-12] high menstrual bleeding associated with the $\mathrm{Cu}-\mathrm{IUD}$ could be due to the mediated development of vasoactive agents other than prostaglandins in the surrounding tissue [13].

The differences among the above studies may be due to the small sample sizes, or the measurement of Doppler indices at specific menstrual cycle periods or times of the day, or by various ultrasonographers. Such contradictory variables had been omitted in the current study. Indeed, the design of the study and the greater number of participants form the main strengths of the study.

Regarding the study's weaknesses. No extension of the duration of follow-up or comparison of other long-acting contraceptive methods was needed

\section{Conclusion}

LNG-IUS-related irregular bleeding was linked to changes in blood flow to the uterine artery that were not apparent among $\mathrm{Cu}$-IUD users. Uterine artery Doppler is an easy, affordable, and readily available method for diagnosing women with irregular uterine bleeding after insertion of the LNG-IUS for contraception. Future research will focus among new users of $\mathrm{Cu}$-IUD on the predictive value of Doppler indices on the uterine artery and subsequent heavy menstruation.

\section{References}

1. Winner B, Peipert JF, Zhao Q, et al. (2012) Effectiveness of long-acting reversible contraception. N Engl J Med 366: 1998-2007.

2. Suvisaari J, Lähteenmäki P (1996) Detailed analysis of menstrual bleeding patterns after postmenstrual and postabortal insertion of a copper IUD or a levonorgestrelreleasing intrauterine system. Contraception 54: 201-208.

3. Momtaz M, Zayed M, Rashid K, Idriss O (1994) Doppler study of the uter- ine artery in patients using an intrauterine contraceptive device. Ultrasound Obstet Gynecol 4: 231234.

4. Järvelä I, Raudaskoski T, Tekay A, Jouppila P (1997) Effect of the levonorgestrel-releasing intrauterine system on the uterine artery pulsatility index in postmenopausal hormone replacement therapy. Ultrasound Obstet Gynecol 10: $350-355$.

5. Jiménez MF, Vetori D, Fagundes PA, de Freitas FM, Cunha-
Filho JS (2008) Subendometrial microvascularization and uterine artery blood flow in IUD-induced side effects (levonorgestrel intrauterine system and copper intrauterine device). Contraception 78: 324-327.

6. Bastianelli C, Farris M, Rapiti S, Vecchio RB, Benagiano G (2014) Different bleeding patterns with the use of levonorgestrel intrauterine sys- tem: Are they associated with changes in uterine artery blood flow? Biomed Res Int 2014: 815127.

7. Cihangir U, Ebru A, Murat E, Levent Y (2013) Mechanism of action of the levonorgestrel-releasing intrauterine system in the treatment of heavy menstrual bleeding. Int J Gynecol Obstet 123: 146-149.

8. Hurskainen R, Teperi J, Paavonen J, Cacciatore B (1999) Menorrhagia and uterine artery blood flow. Hum Reprod 14: 186-189.

9. De Souza MA, Geber S (2006) Doppler color flow analysis of the uterine arteries before and after intrauterine device insertion: A prospective study. J Ultrasound Med 25: 153.

10. Zalel Y, Shulman A, Lidor A, Achiron R, Mashiach S, Gamzu R (2002) The local progestational effect of the levonorgestrel-releasing intrauter- ine system: A sonographic and Doppler flow study. Hum Reprod 17: 2878-2880.

11. Dane B, Akca A, Dane C, Evcimen S, Cetin A (2009) Comparison of the effects of the levonorgestrelreleasing intrauterine system (Mirena) and depotmedroxyprogesterone acetate (Depo-Provera) on subendometrial microvascularisation and uterine artery blood flow. Eur J Contracept Reprod Health Care 14: 240-244.

12. Mutlu I, Demir A, Mutlu MF (2014) Can uterine artery Doppler parame- ters predict copper intrauterine deviceinduced side effects? Eur J Contracept Reprod Health Care 19: 51-56.

13. Järvelä I, Tekay A, Jouppila P (1998) The effect of diclofenac on uterine artery blood flow resistance during menstruation in patients with and without a copper intrauterine device. Hum Reprod 13: 2480-2483.

14. Parks C, Peipert JF (2016) Eliminating health disparities in unintended pregnancy with long-acting reversible contraception (LARC). American journal of obstetrics and gynecology 214(6): 681-688. 